\title{
Obesity among children attending elementary public schools in São Paulo, Brazil: a case-control study
}

\author{
Isabela da Costa Ribeiro ${ }^{1, *}$, José Augusto AC Taddei ${ }^{2}$ and Fernando Colugnatti ${ }^{2}$ \\ ${ }^{1}$ Curso de Nutrição da Pontifícia Universidade Católica do Paraná, Rua Imaculada Conceição, \\ 1155 - Prado Velho, Caixa Postal 16.210, Curitiba, PR, CEP 80215-901, Brazil: ${ }^{2}$ Departamento de Pediatria, \\ Escola Paulista de Medicina, Universidade Federal de São Paulo, SP, Brazil
}

Submitted 4 November 2002: Accepted 20 March 2003

\begin{abstract}
Objectives: To describe obesity among students of public schools in São Paulo and to identify risk factors for this nutritional and physical activity disorder.

Design: Case-control study of obese and non-obese schoolchildren to study risk factors for obesity.

Setting: Anthropometric survey including 2519 children attending eight elementary public schools in São Paulo, Brazil.

Subjects: Schoolchildren aged 7-10 years, of whom 223 were obese (cases; weightfor-height greater than or equal to two standard deviations ( $\geq 2 \mathrm{SD})$ above the median of the National Center for Health Statistics (NCHS) reference population) and 223 were eutrophic (controls; weight-for-height \pm 1 SD from NCHS median).

Measurements: Parents or guardians of the 446 cases and controls were interviewed about the children's eating behaviours and habits.

Results: The prevalence of obesity (weight-for-height $\geq 2 \mathrm{SD}$ ) in the surveyed population was $10.5 \%$. A logistic regression model fitted to the case-control dataset showed that obesity was positively associated with the following factors: birth weight $\geq 3500 \mathrm{~g}$ (odds ratio (OR) 1.83, 95\% confidence interval (CI) 1.21-2.78), child's appetite at meals (OR 3.81, 95\% CI 2.49-5.83), watching television for $4 \mathrm{~h}$ per day or longer (OR 2.07, 95\% CI 1.32-3.24), mother's schooling >4 years (OR 1.85, 95\% CI $1.25-2.75$ ) and parents' body mass index $\geq 30 \mathrm{~kg} \mathrm{~m}^{-2}$ (OR 2.50, 95\% CI 1.43-4.37). Conclusion: The explanatory multivariate model points to preventive measures that would encourage knowledge of the children and their guardians in relation to a balanced diet and a less sedentary lifestyle, such as reducing television viewing. Schoolchildren with a birth weight of $3500 \mathrm{~g}$ or more or whose parents are obese should receive special attention in the prevention of obesity.
\end{abstract}

Obesity is prevalent in several developing countries, affecting children, adolescents and adults. Particularly in those countries experiencing rapid industrialisation and urbanisation, obesity is growing faster and coexists with undernutrition and infectious diseases, becoming one of the greatest public health problems ${ }^{1-3}$.

Cultural factors - operating through gender, ethnic, socio-economic or familial features - are determinants of body weight, by setting moral and social connotations and defining attitudes towards eating and physical activity behaviours ${ }^{4}$. Several authors ${ }^{5-8}$ emphasise the importance of parental obesity as a determinant of children's adiposity. The strong relationship between parental and child obesity appears to involve the combination of genes and the shared environment. In other words, parents not only provide genetic propensities but also behaviours and habits that could influence the expression of these tendencies ${ }^{9,10}$. High birth weight, maternal overweight and high weight gain in the first years of life appear to be the highest risk factors for the development of obesity in childhood ${ }^{11}$.

The rise in obesity prevalence observed in several countries has been associated with an increase in food intake as well as a decrease in physical activity. Sedentary lifestyles associated with urbanisation and industrialisation, such as the proliferation of televisions (TV) and computers, access to means of transportation and the availability of processed food, appear to have little impact on the reduction of energy expenditure if considered separately, but the sum of energy expenditure saved with such technologies has a significant impact on total energy expenditure $^{3,10,12,13}$. Several authors ${ }^{14-16}$ have demonstrated a positive association between the time spent watching TV, reduced physical activity and obesity in children and adolescents. According to Gortmaker et al. ${ }^{6}$, time of TV viewing during childhood is associated positively with obesity prevalence and incidence, 
and negatively with its remission during a 4-year period of follow-up.

According to Neutzling et $a l^{17}$, environmental factors represent important risk factors for overweight and obesity. At a given stage of development, better socio-economic conditions favour nutrition and health aspects, and contribute to the rise of obesity in the population. In 1989, there were about one-and-a-half million obese children in Brazil. The prevalence was higher among girls in the South and Southeast regions ${ }^{18}$. However, among children less than 5 years old, there was a rise in the prevalence of obesity in less developed regions, accompanied by a reduction in obesity prevalence in the country's most developed regions, during the period between the largest national surveys (the Nutrition and Health National Survey in 1989 and the Demography and Health National Survey in 1996) ${ }^{19}$. A rising trend for overweight became evident, and has led to the recognition of obesity as relevant to individual and collective health ${ }^{20,21}$.

Overweight children are at higher risk for several chronic diseases in adult life and there is some evidence suggesting that this association will exist independently of obesity state in adult life $\mathrm{e}^{22,23}$. There is a clear association between obesity and cardiovascular diseases, which are the first cause of death in Brazil. It is estimated that prevention of overweight and obesity could reduce the incidence of cardiovascular disease by at least $30 \%{ }^{21}$.

Considering the global awareness and social mobilisation against childhood obesity, its consequences on adult life and the necessity of early prevention, studies that intend to describe and analyse childhood obesity and associated risk factors are essential to produce information for the control of this nutritional disease. Such studies become more essential in a country like Brazil, which is facing a fast process of nutrition transition. The present study describes obesity among students of elementary public schools in São Paulo City, and identifies risk factors for this nutritional disorder.

\section{Methods}

The present study was part of the RRIDA (Reduction Risks of Illness and Death in Adulthood) project ${ }^{24}$, whose main objective was to develop an interdisciplinary programme directed at elementary public schools to reduce the risk factors for obesity and its associated diseases through the promotion of healthy habits. It was submitted to and approved by the São Paulo Hospital Ethics Committee.

In this case-control study, obese (case) and eutrophic (control) children were identified and studied retrospectively through interviews with their parents or guardians, to determine their nutritional risks, sedentary habits, and individual and family behaviours.

The initial anthropometric survey included 2519 schoolchildren aged 7-10 years, who attended Grades
1 and 2 of eight elementary public schools in Vila Mariana, São Paulo City, Brazil in 2000. In total, 256 obese children (10.5\%) were identified in the total sample. The control group, defined as eutrophic children, was chosen following the order of names appearing in the dataset and matched by sex, age and classroom. To define obesity, weight-for-height greater than or equal to two standard deviations ( $\geq 2 \mathrm{SD}$ ) above the median of the National Center for Health Statistics (NCHS)/World Health Organization (WHO) reference population was used as a cut-off (weight-for-height $Z$-score (WHZ) $\geq 2$ ). A value of $\pm 1 S D$ from the NHCS/WHO median was used to characterise eutrophy (WHZ, height-for age $Z$-score (HAZ) and weightfor-age $Z$-score (WAZ) $>-1$ and $<1)^{25}$.

The team was trained before the beginning of the anthropometric measurements in order to standardise data collection and achieve better accuracy and precision ${ }^{26}$. Digital scales (capacity of $150 \mathrm{~kg}$ and precision of $50 \mathrm{~g}$ ) were used to measure weight. Seca 208 Bodymeter anthropometric tapes were used to measure height. Schoolchildren were weighed while wearing underwear and measured in the vertical position, erect, with parallel feet and ankles, and with shoulders and bottom touching the wall ${ }^{27}$.

Parents were invited to participate in interviews by letter or, in some cases, by phone call. A pre-tested, pre-coded, structured questionnaire was used to collect information about children's eating behaviours and habits as well as their practice of physical activity. As part of the interview, weight and height data of the natural parents were obtained in order to calculate their body mass index (BMI). The cut-off ${ }^{1}$ to determine obesity among parents was $\mathrm{BMI} \geq 30 \mathrm{~kg} \mathrm{~m}^{-2}$.

After the interviews had been carried out and the consistency of the replies was checked, we accounted for 33 losses of obese schoolchildren, 29 due to change of schools and the other four due to parental refusal to participate in the study. In the control group, 21 losses were identified and substituted by the following children in the dataset who fulfilled the matching criteria. The control pairs of lost cases were also removed. After these changes, the final sample consisted of 223 obese children (cases) and 223 eutrophic children (controls). In order to assess selection bias, a comparison between frequencies of risk categories included in the model was made for the missing and remaining children. No significant differences between frequencies were found.

We used contingency tables for the description of frequencies and the study of associations between dependent variables and obesity. The chi-square test was applied at the 0.05 level of significance. The odds ratio (OR) and 95\% confidence interval (CI) were also calculated for the associations.

For studying the individual effect of each independent variable while controlling the effects of others included in the model, we used logistic regression models that 
generated adjusted $\mathrm{OR}\left(\mathrm{OR}_{\mathrm{adj}}\right)$ estimates for obese schoolchildren $^{28}$. The variables to be entered in the model were selected by considering both the significance of the chi-square test and a multiple correspondence analysis ${ }^{29,30}$.

\section{Results}

Frequencies and percentages of categorical factors were obtained for the obese and eutrophic schoolchildren (Table 1). The significant OR values for 12 categorical factors are shown in bold $(P<0.05)$. In this crude analysis, the significant risk factors for obesity were: birth

Table 1 Frequencies and percentages of some categorical factors for obesity in 446 schoolchildren* $^{*}$

\begin{tabular}{|c|c|c|c|c|c|c|}
\hline \multirow[b]{2}{*}{ Variable } & \multirow[b]{2}{*}{$n$} & \multicolumn{2}{|c|}{ Obese } & \multirow[b]{2}{*}{$n$} & \multicolumn{2}{|c|}{ Eutrophic } \\
\hline & & $n_{\text {yes }}$ & $\%$ & & $n_{\text {yes }}$ & $\%$ \\
\hline \multicolumn{7}{|l|}{ Biological } \\
\hline Female sex & 223 & 116 & 52.0 & 223 & 116 & 52.0 \\
\hline $\begin{array}{l}\text { Age between } 84 \text { and } 96 \\
\text { months }\end{array}$ & 223 & 158 & 71.0 & 223 & 157 & 70.5 \\
\hline Birth weight $\geq 3500 \mathrm{~g}$ & 223 & 91 & 41.0 & 223 & 61 & 27.5 \\
\hline \multicolumn{7}{|l|}{ Household condition } \\
\hline House made of brick & 221 & 219 & 98.0 & 219 & 216 & 97.0 \\
\hline Bathroom inside the house & 223 & 216 & 97.0 & 223 & 209 & 93.5 \\
\hline $\begin{array}{l}\text { Garbage collection every } \\
\text { day }\end{array}$ & 221 & 58 & 26.0 & 221 & 40 & 18.0 \\
\hline \multicolumn{7}{|l|}{ Family history } \\
\hline Mother without & 223 & 51 & 23.0 & 223 & 48 & 21.5 \\
\hline Mate & 223 & 136 & 61.0 & 223 & 102 & 45.5 \\
\hline Mat & 223 & 135 & 60.5 & 223 & 116 & 52.0 \\
\hline Par & 199 & 53 & 23.5 & 197 & 25 & 11.0 \\
\hline Famili & 222 & 34 & 15.0 & 222 & 21 & 9.5 \\
\hline $\begin{array}{l}\text { Familial systemic } \\
\text { hypertension }\end{array}$ & 223 & 68 & 30.5 & 222 & 49 & 22.0 \\
\hline Family diabe & 223 & 16 & 7.0 & 222 & 14 & 6.0 \\
\hline \multicolumn{7}{|l|}{ Food history } \\
\hline Breast-feec & 200 & 86 & 43.0 & 193 & 92 & 47.5 \\
\hline Bott & 223 & 148 & 66.5 & 223 & 145 & 65.0 \\
\hline & 223 & 177 & 79.5 & 223 & 180 & 80.5 \\
\hline Family & 223 & 208 & 93.0 & 223 & 204 & 91.5 \\
\hline $\begin{array}{l}\text { Very good appetite at } \\
\text { meals }\end{array}$ & 223 & 121 & 54.0 & 223 & 53 & 23.5 \\
\hline $\begin{array}{l}\text { Very good appetite at } \\
\text { intervals }\end{array}$ & 223 & 75 & 33.5 & 223 & 43 & 19.5 \\
\hline snacks & 223 & 116 & 52.0 & 223 & 144 & 64.5 \\
\hline & 223 & 214 & 96.0 & 223 & 221 & 99.0 \\
\hline $\begin{array}{l}\text { Visible fat: little or nothing } \\
\text { eaten }\end{array}$ & 223 & 175 & 78.5 & 223 & 183 & 82.0 \\
\hline \multicolumn{7}{|l|}{ Eating/behavioural habits } \\
\hline Meals at table & 223 & 76 & 34.0 & 223 & 81 & 36.5 \\
\hline M & 223 & 182 & 81.5 & 223 & 186 & 83.5 \\
\hline $\mathrm{Me}$ & 223 & 23 & 10.5 & 223 & 37 & 16.5 \\
\hline Wa & 223 & 142 & 63.5 & 223 & 137 & 61.5 \\
\hline $\begin{array}{l}\text { Watching TV for } \geq 4 \mathrm{~h} \\
\text { per day }\end{array}$ & 223 & 78 & 35.0 & 223 & 46 & 20.5 \\
\hline $\begin{array}{l}\text { Leisure-time sedentary } \\
\text { activities }\end{array}$ & 223 & 54 & 24.0 & 223 & 30 & 13.5 \\
\hline hysica & 223 & 21 & 9.5 & 223 & 23 & 10.5 \\
\hline Walks $t$ & 223 & 120 & 54.0 & 223 & 142 & 63.5 \\
\hline
\end{tabular}

$\mathrm{BMI}$ - body mass index.

* The $P$-value is taken from the corresponding chi-square test; significant values $(P<0.05)$ are given in bold. weight $\geq 3500 \mathrm{~g}$, garbage collection every day, maternal schooling of $>4$ years, parental obesity, family hypertension, very good appetite at meals and intervals, watching $\mathrm{TV}$ for $\geq 4 \mathrm{~h}$ per day, and sedentary activities during leisure time. On the other hand, healthy snacks, adequate fat consumption and walking to school proved to be significant protective factors. Their intensity, estimated by the crude OR, ranged from 1.50 to 4.65 . The other variables studied did not constitute significant risk factors.

All the independent variables considered in the regression model (Table 2) were binary categorical variables that proved to be statistically significant $(P<0.05)$. Among the variables considered in the final model, three were related to former characteristics of schoolchildren and their parents. So, birth weight of $\geq 3500 \mathrm{~g}$, parents' obesity (BMI $\geq 30 \mathrm{~kg} \mathrm{~m}^{-2}$ ) and maternal schooling of $>4$ years were identified as factors that increase the risk of obesity in schoolchildren $\left(\mathrm{OR}_{\mathrm{adj}}\right.$ 1.64, 2.51 and 2.14, respectively). Two other variables included in the final model were measurements of the schoolchildren's behaviour. Having a very good appetite at meals, as perceived by parents or guardians, represented the strongest risk factor $\left(\mathrm{OR}_{\mathrm{adj}}\right.$ 3.67). Another behavioural characteristic, number of hours watching TV, is a proxy of the schoolchildren's sedentary behaviour. The group who watched TV for $\geq 4 \mathrm{~h}$ every day had a $1.89\left(\mathrm{OR}_{\mathrm{adj}}\right)$ times higher risk of being obese, compared

Table 2 Obesity prevalence, and crude and adjusted odds ratios (95\% confidence interval), for socio-economic, biological and behavioural variables $(n=446)$ in a logistic regression model. Each variable was significant at the $<0.05$ level in the bivariate analysis

\begin{tabular}{|c|c|c|c|c|}
\hline Variable & $n$ & $\begin{array}{l}\text { Obesity } \\
\text { prevalence } \\
(\%)\end{array}$ & $\begin{array}{c}\text { Crude OR } \\
(95 \% \mathrm{Cl})\end{array}$ & $\begin{array}{l}\text { Adjusted OR } \\
(95 \% \mathrm{Cl})^{*}\end{array}$ \\
\hline \multicolumn{5}{|l|}{ Birth weight } \\
\hline$<3500 \mathrm{~g}$ & 294 & 45.0 & 1.00 & 1.00 \\
\hline$\geq 3500 \mathrm{~g}$ & 152 & 600 & $\begin{array}{l}1.83 \\
(1.21-2.78)\end{array}$ & $\begin{array}{l}1.64 \\
(1.04-2.60)\end{array}$ \\
\hline \multicolumn{5}{|l|}{ Parent's BMI† } \\
\hline$<30 \mathrm{~kg} \mathrm{~m}^{-2}$ & 318 & 46.0 & 1.00 & 1.00 \\
\hline$\geq 30 \mathrm{~kg} \mathrm{~m}^{-2}$ & 78 & 60.0 & $\begin{array}{l}2.50 \\
(1.43-4.37)\end{array}$ & $\begin{array}{l}2.51 \\
(1.43-4.43)\end{array}$ \\
\hline \multicolumn{5}{|l|}{ Mother's schooling } \\
\hline$\leq 4$ years & 208 & 42.0 & 1.00 & 1.00 \\
\hline$>4$ years & 238 & 57.0 & $\begin{array}{l}1.85 \\
(1.25-2.75)\end{array}$ & $\begin{array}{l}2.14 \\
(1.38-3.32)\end{array}$ \\
\hline \multicolumn{5}{|l|}{ Appetite at meals } \\
\hline Poor, regular, good & 272 & 37.5 & 1.00 & 1.00 \\
\hline Very good & 174 & 69.5 & $\begin{array}{l}3.81 \\
(2.49-5.83)\end{array}$ & $\begin{array}{l}3.67 \\
(2.33-5.78)\end{array}$ \\
\hline \multicolumn{5}{|c|}{ Hours of TV watching per day } \\
\hline$<4$ & 322 & 45.0 & 1.00 & 1.00 \\
\hline$\geq 4$ & 124 & 63.0 & $\begin{array}{l}2.07 \\
(1.32-3.24)\end{array}$ & $\begin{array}{l}1.89 \\
(1.15-3.11)\end{array}$ \\
\hline
\end{tabular}

OR - odds ratio; $\mathrm{Cl}$ - confidence interval; $\mathrm{BMI}$ - body mass index. *Adjusted for independent variables included in the final model. †Of the interviewed subjects, 396 were parents. 
with the group of schoolchildren who watched $<4$ h of TV daily.

\section{Discussion}

The prevalence of obesity found in the studied population was twice $(10.5 \%)$ that reported in the last national survey (1989) for the same age group ( $4.2 \%$ for males and $4.3 \%$ for females). The survey reported that the prevalence of obesity in children from the South and Southeast of Brazil was $6.1 \%$ and $5.4 \%$, respectively. Therefore, the percentage of obese schoolchildren in this study was higher than expected for children from the South and Southeast, the most developed regions of Brazil ${ }^{18}$.

The variable mother's schooling showed an intense and positive association with children's obesity (OR 1.85, 95\% CI 1.25-2.75). The mechanisms by which higher mother's schooling could determine a higher risk of obesity among her children are related to the mother's capacity to incorporate information to adapt food and leisure practices to the new conditions of the urban and industrialised environment.

In an analysis of the changes that occurred between 1989 and 1996 among Brazilian children aged less than 5 years, Taddei ${ }^{19}$ described an increase of obesity in the Northeast region among children whose parents had more than 4 years of schooling. On the other hand, there was a profound reduction among children whose parents had the same schooling and lived in the South region. These facts showed two opposite movements in two regions facing different stages of the nutrition transition.

The subjects of our study represent the lower economic level of São Paulo, one of the most developed Brazilian cities, and show characteristics and behaviours observed for the population of the Northeastern region, one of the least developed in Brazil. Similarly to what was found in the Northeastern region ${ }^{19}$, mothers with higher schooling would be part of a group that had already incorporated urbanised and industrialised patterns and habits, which are promoted by the media and stimulated by development. However, they still do not have enough knowledge to adapt these consumption standards in order to prevent obesity of their children.

The overweight and obesity prevalence in adolescents, evaluated during the Nutrition and Health National Survey in 1989, was also higher among those with higher schooling and income. Male adolescents with higher income levels had three times greater chance of being overweight than the lower-income group. The same risk was two times higher for females ${ }^{17}$.

In developed societies, there is a negative association between obesity and socio-economic conditions, mainly among women. However, for developing societies a complete inversion of the relationship between obesity and socio-economic conditions is observed ${ }^{31}$. A reason that may explain this difference is a false recognition of obesity as an indicator of wealth in developing countries. Moreover, dieting, nutrition knowledge, slim aesthetic standards and daily practice of physical activity are prevalent in the population of developed societies.

The relationship between birth weight and childhood or adulthood obesity is still controversial. The results of the present study suggested the existence of an obesity risk almost two times higher among schoolchildren with birth weight $\geq 3500 \mathrm{~g}$, compared with those whose birth weight is $<3500 \mathrm{~g}$. This association was also observed by Whitaker and Dietz ${ }^{32}$ in seven of eight revised studies. Analysis of data for Italian children (4-12 years old) also showed that high-birth-weight children presented a higher relative risk for obesity during childhood ${ }^{33}$.

In this study, maternal obesity was strongly associated with their children's obesity (OR 2.50, 95\% CI 1.43-4.37). This association has been well described in the literature, and involves genetic inheritance and factors pertaining to the development of habits having the parents as reference. Family standards that favour the appearance of adiposity are the result of genetic and environmental interaction ${ }^{7}$. In a sample of 735 Italian schoolchildren aged $7-11$ years, a strong association between parents' obesity and children's obesity was observed ${ }^{8}$.

Long time spent watching TV was strongly associated with obesity in the schoolchildren studied (OR 2.07, 95\% CI 1.32-3.24). The results suggested that children who watch TV for $\geq 4 \mathrm{~h}$ per day have a higher chance of being obese, probably because, besides the inactivity, watching TV is usually linked to the consumption of snacks high in saturated $\mathrm{fat}^{3}$. In addition, practically the only foodstuffs advertised during children's TV shows are high in energy and fat density, such as snacks and fast foods ${ }^{6}$. Hanley et $a l^{34}$ observed that subjects who watched 5 or more hours of TV per day were at 2.5 times higher risk for overweight compared with those who watched $2 \mathrm{~h}$ or less (OR 2.52, 95\% CI 1.06-5.98).

Steps for obesity prevention among Brazilian schoolchildren must focus on reducing sedentary practices, particularly reducing time of TV viewing and limiting the time of physical inactivity, that is usually associated with the consumption of energy-dense foods high in saturated fat and sodium. Schoolchildren of obese parents and those born with high birth weight ( $\geq 3500 \mathrm{~g}$ ) should be specially monitored, and higher maternal schooling must be followed up with better quality information in order to transform information and culture into a protective factor against obesity.

\section{Acknowledgements}

We would like to acknowledge the Fundação de Amparo à Pesquisa de São Paulo (FAPESP) and also the dedicated team who contributed to this study, which included interviewers, computer technicians and typists. 


\section{References}

1 World Health Organization (WHO). Obesity: Preventing and Managing the Global Epidemic. Report of a WHO Consultation on Obesity. Geneva: WHO/NUT/NCD, 1998.

2 Bellizzi MC, Dietz WH. Workshop on childhood obesity: summary of the discussion. American Journal of Clinical Nutrition 1999; 70(Suppl.): 173S-5S.

3 Shetty PS. Obesity in children in developing societies: indicator of economic progress or a prelude to a health disaster? Indian Pediatrics 1999; 36(1): 11-5.

4 Jebb SA. Aetiology of obesity. British Medical Bulletin 1997; 53(2): 264-85.

5 Guillaume M, Lapidus L, Beckers F, Lambert A, Björntorp P. Familial trends of obesity through three generations: the Belgian-Luxembourg child study. International Journal of Obesity 1995; 19(Suppl. 3): S5-9.

6 Gortmaker SL, Must A, Sobol AM, Peterson K, Colditz GA, Dietz WH. Television viewing as a cause of increasing obesity among children in the United States, 1986-1990. Archives of Pediatrics \& Adolescent Medicine 1996; 150: 356-62.

7 Cutting TM, Fisher JO, Grimm-Thomas K, Birch LL. Like mother, like daughter: familial patterns of overweight are mediated by mothers' dietary disinhibition. American Journal of Clinical Nutrition 1999; 69: 608-13.

8 Maffeis C, Provera S, Filippi L, Sidoti G, Schena S, Pinelli L, et al. Distribution of food intake as a risk factor for childhood obesity. International Journal of Obesity 2000; 24: 75-80.

9 Parsons TI, Power C, Logan S, Summerbell CD. Childhood predictors of adult obesity: a systematic review. International Journal of Obesity 1999; 23(Suppl. 8): S1-107.

10 Hill JO, Wyatt HR, Melanson EL. Genetic and environmental contributions to obesity. Medical Clinics of North America 2000; 84(2): 333-46.

11 Engstrom EM, Anjos LA. Relationship between maternal nutritional status and obesity in Brazilian children. Revista de Saúde Pública 1996; 30(3): 233-9.

12 Parizkova J, Hills A. Childhood Obesity - Prevention and Treatment. Boca Raton, FL: CRC Press, 2001.

13 Burrows RA. Prevención y tratamiento de la obesidad desde la niñez: la estrategia para disminuir las enfermidades crónicas no transmisibles del adulto. Revista Medica de Chile 2000; 128: 105-10.

14 Bernard L, Lavallée C, Gray-Donald K, Delisle H. Overweight in Cree schoolchildren and adolescents associated with diet, low physical activity and high television viewing. Journal of the American Dietetic Association 1995; 95(7): $800-2$.

15 Durant RH, Thompson WO, Johnson M, Baranowski T. The relationship among television watching, physical activity, and body composition of 5- or 6-year-old children. Pediatric Exercise Science 1996; 8: 15-26.

16 Andersen RE, Crespo CJ, Bartlett SJ, Cheskin LI, Pratt M. Relationship of physical activity and television watching with body weight and level of fatness among children results from the Third National Health and Nutrition Examination Survey. Journal of the American Medical Association 1998; 279(12): 938-42.
17 Neutzling MB, Taddei JAAC, Rodrigues EM, Sigulem DM. Overweight and obesity in Brazilian adolescents. International Journal of Obesity 2000; 24: 1-7.

18 Taddei JAAC. Epidemiologia da obesidade na infância. In: Fisberg M. Obesidade na Infância e Adolescência. São Paulo: Fundação BYK, 1995.

19 Taddei JAAC. Desvios nutricionais em menores de cinco anos: evidências dos inquéritos antropométricos nacionais. Tese de Livre-Docência, Universidade Federal de São Paulo/Escola Paulista de Medicina, São Paulo, 2000.

20 Dietz WH. Childhood obesity: susceptibility, cause and management. Journal of Pediatrics 1983; 103: 676-86.

21 Brasil Ministério da Saúde. Plano Nacional para a Promoção da Alimentação Adequada e do Peso Saudável. Brasília: Brasil Ministério da Saúde, 1999.

22 Must A, Jacques PF, Dallal GE, Bajema CJ, Dietz WH. Long term morbidity and mortality of overweight adolescents: a follow-up of the Harvard Growth Study of 1922 to 1935. New England Journal of Medicine 1992; 327(19): 1350-5.

23 Freedman DS, Dietz WH, Srinivasan SR, Berenson GS. The relation of overweight to cardiovascular risk factors among children and adolescents: The Bogalusa Heart Study. Pediatrics 1999; 103(6): 1175-82.

24 Taddei JAAC, Ancona FL. Reduction Risks of Illness and Death in Adulthood [online]. Available at http://www. unifesp.br/dped/disciplinas/nutricao/rram.html. São Paulo, Brazil, December 2001.

25 World Health Organization (WHO). Physical Status: The Use and Interpretation of Anthropometry. Geneva: WHO, 1995.

26 Habicht JP. Estandarización de métodos epidemiológicos cuantitativos sobre el terreno. Boletín de la Oficina Sanitária Panamericana 1974; 76(5): 375-84.

27 Jelliffe DB. Evaluación del Estado de Nutrición de la Comunidad. Geneva: Organización Mundial de la Salud, 1968.

28 Schlesselman JJ. Case-Control Studies - Design, Conduct, Analysis. Oxford: Oxford University Press, 1982.

29 Lebart L, Morineau A, Piron M. Statistique Exploratoire Multidimensionelle. Paris: Dunod, 1995.

30 Hosmer DW, Lemeshow S. Applied Logistic Regression. New York: Wiley, 1989.

31 Stunkard AJ. Factores determinantes de la obesidad: opinión actual. In: Organización Panamericana de la Salud (OPS)/Organización Mundial de la Salud (OMS), ed. La Obesidad en la Pobreza: Un Nuevo Reto para la Salud Pública. Washington DC/Geneva: OPS/OMS, 2000.

32 Whitaker RC, Dietz WH. Role of the prenatal environment in the development of obesity. Journal of Pediatrics 1998; 132 : $768-76$.

33 Maffeis C, Micciolo R, Must A, Zaffanello M, Pinelli L. Parental and perinatal factors associated with childhood obesity in north-east Italy. International Journal of Obesity 1994; 18: 301-5.

34 Hanley AIG, Harris SB, Gittelsohn J, Wolever TMS, Saksvig B, Zinman B. Overweight among children and adolescents in a Native Canadian community: prevalence and associated factors. American Journal of Clinical Nutrition 2000; 71 : 693-700. 